\title{
"Writing out of One's Own Experience": An Interview with James Plunkett
}

\author{
Rosa González \\ Universidad de Barcelona
}

Rosa González Do you think that the fact that you started writing short stories has affected your style and has dictated the structure of your novels - which are like a tapestry of interwoven stories?

James Plunkett Yes, I started writing - well, I started writing at any age — but I mean, I began to contribute stories to The Bell. Sean O'Faolain was the editor, Frank O'Connor was a kind of deputy editor, and Peadar O'Donnell was really the man who got the money. Anyway, I sent some stories to O'Faolain. They were rather romantic stories, and he said: "This is still wrong, and this is not good, and you are not writing out of your own experience. Write out of your own experience." At twenty one I felt that I had no experience at all, but of course you have, it just hasn't percolated.

Then I wrote a story called "Working Class." I was working as a clerk in the Gas Company in D'Olier Street and I was walking along the quays, and there was that misty spinning rain that you get here in Dublin, and I saw this lady, an elderly woman, poor class. In those times - the nineteen forties - they wore black shawls round their heads. When she passed me she was crying, and I began to wonder what has happened to her? has she a daughter or a son that's very ill in hospital? has he had an accident? is he dead, or whatever? Well, I decided that the husband had died and I made up a story around this. Then I just put the story down, sent it to Sean O'Faolain and he accepted it. And then, another one I wrote I called "Hurler on the Ditch" which is an expression here for, you know, the person who is not playing the football or the hurley but is sitting on the ditch - he always knows far more than anyone else, he is observing too, you know. I called it "Hurler on the Ditch" but Sean the publisher said he'd like to change the title to call it simply "The Mother."

So, that was that, he published those two and that started me off. These were stories of fifteen hundred words, where you tended to have just one person, and everything is seen through his mind or his action. After a while I got a bit tired of that because there seemed to be no room for anything else. 
On the other hand, for a long time I couldn't understand the poetry of T.S. Eliot. I found the syntax very difficult. You know, his early stuff, "The Hollow Men" and so on. It's kind of contrapuntal in the sense that he can shift from one thing to another completely different, and yet when it's finished there is a totality of the various aspects. And so I began to write and copy the contrapuntal style. I also studied music and I played the violin and the viola - I play it very badly now but I used to play it not too badly-, and my wife played the piano. So then I launched out on three stories, very long stories, between ten and twelve thousand words, and Peadar O'Donnell published them. And these were in that contrapuntal style. You know, you deal with this and you deal with that, and then you deal with this and that and so on, you keep like a motif, well, not a motif, it's more than a motif, it's an episode, and that's in that contrapuntal style, switching from one thing to another, to make a tapestry. It means that sometimes you have to go back and change something because you changed your mind on page 203 and you have to go back to page 60 to alter that, but I don't mind that. So that's how I felt the contrapuntal style gave me more roundness, though it is also hard to establish, it's very hard to remember yourself, what shall I do, you know. But in any case, when you get it together I feel that it gives a more comprehensive view of the subject.

Then, you see, I loved O'Casey; he wrote about what he called the "submerged city." And of course, I liked Joyce and everything Joyce wrote about I knew: I had been born in Sandymount, I had walked the Strand, I had lived in Upper Pembroke Street - not in a big Georgian house, but a flat in Upper Pembroke Street. As a boy I used to go down to pedal my motorcar, and round the Green in Stephen's Green and after that I'd go into the Museum or the National Gallery - I was brought there to be educated. I loved Joyce, I loved his short stories. I didn't care much for Stephen Hero. Of course, I hadn't read it then for it wasn't published until later on, but when I did read it I didn't like Stephen very much - a very self-conscious young man, looking at his navel all the time. When it became $A$ Portrait of the Artist of course I adored it, and Ulysses too. Finnegans Wake, I know, I can even quote from it, but in its whole totality it's too weary.

So, when I wrote my first novel, Strumpet City, I wanted to write about the 1913 strike because I knew all these men. It doesn't mean I was there, but I was secretary of the Workers Union, and they all gathered in the Union, and they talked. And I knew Big Jim Larkin himself. I had been a member of the Section Committee since the age of eighteen, but in the last two years I worked as Branch Secretary with Big Jim. In the novel I wanted to get in the whole of that period, not just the poor and down-and-outs - which O'Casey has - I wanted to get in Joyce's kind of seedy gentility, and then I wanted to get in the employers' side with such a person as Yearling and then the priests, through Father Giffley and Father O'Connor. That's what I chose, and that of course demanded a contrapuntal treatment.

I wanted to go round the picture; I didn't want Larkin, I wanted Dublin itself to be the hero, you know, in a mystical kind of way, with Larkin as a sort of "Deus ex machina." Just keep him in the background, for otherwise he would overpower the thing. I think you either write a biography or you cannot write a fiction about a person, a living person so near you, and 1913 was very near one in historical terms. Anymore than I think you can write a fiction about Parnell, you know, it's too near. But you can write a fiction about 
somebody way back in the Elizabethan times like the great $\mathrm{O}$ 'Neill or people of that kind, and even now maybe Daniel O'Connell, but I am not sure.

R. G. You have just mentioned your interest in Joyce and O'Casey. Are there any other writers with whom you feel particular affinity? Maybe Liam O'Flaherty?

J. P. Oh yes, first of all I think that his animal stories, his nature stories are absolutely superb, "The Little Lambs Go out to Sea" or "The Three Lambs" or whatever. And I think his Famine is a very fine book. There is not a character in them, they are all stereotypes, they are cardboard, but the story comes through, which is the great thing, and of course, the massive theme. You see, Strumpet had a massive theme, and so had Famine. But I loved The Informer too, and I liked his tight style and his short sentences, a bit like Hemingway but very Irish too, he is absolutely bang on right.

And Frank O'Connor, I liked his dialogue. O'Connor's dialogue is just superb, he did his job beautifully, and it's so true, it rang true, you could hear that person talk. Some people don't write dialogue at all, it's stiff, stiff, nobody would ever say anything like that. I'm afraid that up to a point I prefer his polemical books, but nevertheless his stories are very very good.

Then there is Peadar O'Donnell, of course. He wrote a beautiful book called Islanders, a very fine book, very simple. Quite away from me too, for it was written about an island people, rather like the Aran islands, except these were islands off the coast of Donegal. But it moved me much, it moved everybody very much, not just me, it moved a whole big public in America too, even though they wouldn't know an egg from a cucumber.

So, they were the influences. And as to structure, Evelyn Waugh's stories I thought were very well structured. There is a lot of surprise in them too, though they are quite plausible, like that awful story where a fellow is captured and this native chief keeps him in captivity to read Dickens to him over and over again.

R. G. Though Jim Larkin hardly figures as a character in Strumpet City, wouldn't you say that his belief in the dignity of the individual and in the human potential of the labouring class inform your account of the Dublin lock-out and your portrayal of fully realised flesh-and-blood characters?

J. P. Yes. And also because I drew my characters from ordinary Dublin life, I just put them into the situation. I knew lots of them as older men, but I could imagine what they were like as younger men. Being the Union's Secretary, I would have daily meetings and there would be maybe twelve men, and they were all different characters, and they were very very intelligent men. They had left school when they were twelve or thirteen but, as they used to say, they had attended the university of life. There were good ones and bad ones and in-between ones, but they were characters too. Rashers was a character who used to pass me when I was a child, and there would be a gang of us, you know, and the others used to jeer at him, and I hated that. I used to say: "Ah listen, give up, leave him alone" and then I would get a belt for myself because I was a pretty small boy at the time. He was a weird character, he wore a couple of coats and there would be no buttons on them so he 
would tie a length of rope round his waist and he used to carry a bag on his back with his belongings...

\section{R. G. And he had a dog?}

J. P. No, I gave him the dog because, you see, I used another character as well. I used to serve Mass and... (I keep talking a lot about religion, but that's because I was brought up that way.) Anyway, I used to serve Mass in University Church, which was Cardinal Newman's Church, which again was the church for the University. I used to go there in my troubled teens, to Father Burke; he was the chaplain for the university, a lovely man, you could talk to him about everything, without embarrassment. And there was a little chap called Jack Jackson, who was the stoker for the boiler, and being youngsters, we used to love to go down to the boiler house. It was a filthy place, full of dust and coke. We would sit on the coke and we used to make tea and smoke cigarettes, and Jack would talk about this and that; he hadn't much in his head at all. For instance, he had worked making munitions or something like that in Scotland during the First War, and he would tell us about the great long journey he had from Glasgow in Scotland. That kind of thing. Anyway, that's how I put Johnny Forty Coats into the boiler house and that's how Rashers came about as well. Yearling was a kind of... an embryo Bernard Shaw. Father O'Connor was a man who had great admiration for St Vincent de Paul and who wished to do charity in a poor parish. Well, he thought he could do it, but he was a snob to a certain extent and he couldn't bear the smell of humanity; and this is what Father Giffley, the whiskey priest can't bear, and he says something like: "Father O'Connor I saw you serving the Holy Communion, the body of Christ, and the loathing in your face." People hated O'Connor and thought he was an awful character, but at the same time he was doing his best, he just couldn't get over this little snobby thing - I suppose certain fastidiousness - or he just didn't like the smell of damp, dirty clothes, unwashed bodies, you know, that sort of thing.

R. G. Most descriptions of Larkin have highlighted his arrogant personality, his aggressive methods and quick temper that led him to clash with other leaders of the Union and with the Sinn Féin. In contrast to this, you have mentioned Larkin's "tenderness towards the weak and unfortunate and his almost feminine sensitivity to human suffering." ("Jim Larkin. A Memoir.") This seems to imply that there was also a gentler side to his personality.

J. P. He was like the weathercock, as they say; he just went that way with every breeze. It was all right if you talked soft and reasonably to him, but if you tried anything on, like "Oh Mr Larkin, that's all very well but there's this and that and the other," suddenly he would change and say "How would it appear if they were all out in the morning? There would be a small strike." That's exactly how he would bang.

There was an engineer who used to negotiate with the Gas Company, and he'd say to us: "Ah, you say that, but how do we know what the other fellow is going to do?" You see, the Big Man - as they used to call him - was still alive, very old, but still alive. He would switch at any moment from this to that but his compassion was part of his nature; 
he couldn't not be compassionate. With a defenceless person he was unfailingly protective; sometimes wrongly, because he might be a bit of a rogue, the fellow he was protecting, but it doesn't matter, he would protect him.

Oh, there were many incidents. For instance, I remember going down one Sunday morning. I just stopped going in on Sundays, I had enough with six days a week. Sunday was family day, I had a couple of kids growing up, very small, and a wife too that had to be attended. But I remember I had to go in one Sunday morning - there was a strike or something - and there was a person called Frank - he was a labour man, he died of cancer some years ago, but he was very young at that time. It was a very hot Sunday, and there was this stone stairs going, like from the bottom way up to the top, to Larkin's office, and you couldn't get by with the queue on the stairs, and Frank came down and stood at the door with me. I said: "I'm not pushing through that, what the Hell is going on?" "Ah - he said - the Big Man is hearing confessions."

He was more than a trade union leader: the women would come up to him - the wives, you know. You must remember that in those days it was mostly the men who were working and the wives would be at home, and maybe the husbands wouldn't be giving them enough money, or maybe the young boy was getting into bad ways. So, they would ask him to talk to the husband or the boy; he was very human and compassionate. At Christmas he used to send out cakes and fowl, or whatever he would get from employers. And Barney Conway would have to go round to deliver this. That's how you get Keever in Strumpet City bringing the poor packs - or the pucks, as he calls them. Barney was very fond of drink, a big huge man; he would throw a policeman into the Liffey, but he was as gentle as anything, well, gentle enough until he got a belt or something, but otherwise, a gentle fellow, and with a sense of humour. Barney came in after a long Christmas Eve delivering these things and Jim called him in: "Barney, how did you get on?" and he saw that Barney was a bit flustered: "Barney, will you sit down there" and of course Barney went to sit down but he missed the chair and hit the floor and the Big Fellow said: "Oh Barney, I knew it, you've been drinking, and you are drunk and "stotious," you're a disgrace. Pick yourself up." And Barney picked himself up and said "Jim, did you ever hear about what the good Book said: "The just man fell seven times." And then Jim would say: “Ah Barney, you're incorrigible."

\section{R. G. How did you get on with Larkin?}

J. P. He used to call me to his office: "Young Kelly, I want to talk to you." I was only twenty-six when I joined the staff — he was seventy-one — but he took a fancy to me. I had done a lot of pretty meticulous work for him, I got the books in order, and he was very pleased with this, but he also liked talking to me - you know what happens with very old and young people - and he would call me for a chat, it didn't matter if I had a lot of work to do. For instance, he would look out of the window at Trinity College. The messenger boys in those days would be little kids about fourteen, and they would be delivering for a grocer or a butcher in a bike; they carried a huge big basket, very heavy, and it was very hard to control the handlebars. One day, it was pouring rain, and the first thing he looked at the congestion at the gates of Trinity, and he said: "You see that there, it's causing 
terrible trouble, see that boy passing, that poor child will be knocked down. All that will have to be pushed back." Imagine, the whole of Trinity had to be pushed back! because of the boy, you see. So that's the way he was.

R. G. You have said that what makes a writer write "is his attempt to understand his own memories" ("The Short Story") and that the experiences of childhood and early youth are "the small store of material which is virtually all a good writer can ever draw on." "“The Boy on the Back Wall") Is this the reason why your novels always deal with past periods and the characters themselves tend to look backward rather than forward?

J. P. Well, I believe that after the age of about twenty-two or thereabout, nothing much happens. Now, this seems an extraordinary thing to say, but I think that the things that determine your character and your attitude towards life, your experiences, all happen between the cradle and about the majority of twenty-one. Think for example the way Proust draws on memory all the time.

As Sam Beckett said, there are two kinds of memory. One is the memory that tells me I have to meet Rosa González on Monday, you know, or that I've got to do something in the house, but the other memory is different altogether; it's the memory that keeps coming back and coming back and coming back, and you wonder why is this happening, because there are no consequences in the matter of things happening. For instance you are walking on the street and your lace becomes untied and you want to tie it and you look for somewhere to, you know, place your foot, and you remember it all you life! Why the hell! I mean, that's extraordinary. And things from childhood, like I always remember my grandfather's house, where I was born.

Talking about imagination, Frank Budgen once asked Joyce: "What is imagination?" and Joyce thought for a while and said: "Budgen, what is imagination except memory?." Indeed, look at Joyce's books with that in your head and you'll see that it is mostly in his memory, he doesn't write about political occasions, he never made political statements in his life, I don't think, but it is all memory. And the characters are there, he goes for reality, he uses real characters, and you've no doubt in the world who they are, you know, like the Citizen who is Cusack, the founder, well not the founder but he was a very important person in the G.A.A., the Gaelic Athletic Association.

So, that's it, these things you remember, like tying a shoelace, or sitting on pipes going out by the Coast Guard Station towards the Pigeon House with your aunt, and sitting on these pipes because a cinder has gone into your eye, and she gets a hankie to get it out. And you wonder: "Why do I remember that?"

Other things I remember well because they were quite shocking: there was a place called the Copper Lake and people were foolhardy and they'd go when the strand was ebbed. You could always go through this stream but there was a whirlpool in it somewhere, and people were always getting drowned in it. Once with a friend of mine we walked across the strand to a kind of beach. We were lying there in bathing togs, of the old kind - you know, black, covering all the way, with shoulder straps - when we saw that body lying there. It had been drowned, it had been in the sea for some weeks, the flesh had 
been eaten and there were crabs running in and out, the crabs had eaten the flesh, it was quite shocking.

Now, you would remember that because that was a shocking thing. But on the other hand, my paternal grandmother had relatives in the mountains of south county Dublin, and she used to go out and milk the cows. And I'd go out there the odd time too. I always remember going there and having boiled egg and homemade bread and jam. So why? God knows, there are much more important things. But to me, each of these things became little pictures, as it were, kind of hanging here in a gallery and I eventually came to realise that they were little things of some kind wanting to get out, wanting to be expressed, something that would trigger at the heart of the imagination, which is almost subliminal, you know, and that's what you grow on.

So, when writing stories, one of these things would come in. I would start with one of these things. That would be the middle or something, like the nucleus, and around that a whole story would begin to develop.

Also, I loved the mountains - which were always visible from the city - and I was always coming out for walks alone. Which is not a very good thing to do. They look small mountains but they are very wild - at least they were in those days. One day I was crossing down a mountain to get back to the city, and I stumbled and I hurt my ankle. And then I suddenly thought: "If you had broken your ankle what would you do here? you would be lying here for days until some shepherd came along looking for a sheep or something and found you there." Then I noticed there was one of these wonderful sunsets that you get here - red and blue and green - the kind that make you think of religion, you know, and I said: "God, this is the kind of day before the end of the world, and God will come down with all his majesty to you." Then a pigeon came, a homing pigeon; it was very tired, probably it got disorientated, it was trying to find its way home. Later that evening, after I got home, there was a thunderstorm and I imagined this pigeon flying against the storm, labouring to get home, and then I thought "supposing that poor old pigeon had broken its leg or something like that," and that's how the whole thing came down and it's called "The Trusting and the Maimed"; all around that experience, except it began to grow grow grow grow. I knew there was something there I had to say, because it was ethereal in the sense that my feet were not underground, I was now a mystic really, in my thinking, like Saint John of the Cross. So, that was another picture; I could give you a picture for nearly every story. Like the Dublin Fusilier I saw between Nelson Pillar and the statue of O'Connell. The street facing Nelson Pillar had all sorts of restaurants and through the grills you could smell food, and this poor devil came limping across, obviously a Dublin Fusilier, he was shell-shocked too, and he used to stop at the top of Grafton Street and start directing the traffic. So anyway, that was another story.

R. G. Does the fact that you rely so much on memory rule out the possibility of your writing a novel set in present day Ireland?

J. P. Well, people have asked me will you not write about the sixties and I said no, I pulled down the shutter. Well, Joyce pulled down the shutter in 1904. I mean, I don't know really, and I don't care what's going to happen. Because I know in my heart and soul that it must 
be deeply related to what went before and there is no great division between past and present. You are probably very much as your parents were, whether you liked them or hated them, or you didn't care. Something of that is in you, and little things will remind you of friends you knew in school, or incidents. They don't seem very important, they don't sound important at all, but they are the trigger, and that sets the mind, the memory, the imagination. Joyce is right, what is imagination, except memory? It is the thing that you start expanding on; it doesn't mean you put down a, b, c, d, no, that's what the imagination is for, it comes in after the memory; memory first, then imagination.

R. G. In Farewell Companions Cunningham says: "There are three mortal sins in Holy Ireland. Not going to mass, sexual activity of any shape or make, and eating meat on a Friday." Do you find things have changed much in the last decades?

J.P. Oh very much, we all eat meat on a Friday now, because there is a general dispensation, but I didn't mean it in that way. I meant that these three apparently trivial things were the only sins in the Book. Nothing about rob your neighbour, cheat him, calumniate him, or commit enormous injustices, which, in my view of Christianity, would be the real sins.

R. G. In "Myth and Reality" you have said that "for mature men of my childhood, even for those who had suffered grievously from its intolerance, [the Church] guarded a Truth which was better than the sum of all its wrongheadedness. And so it came about with me ... This is partly a matter of history but, more so, an inherited disposition of race." Would this explain why the characters in your last two novels conform quite easily to the strict puritanical ethos in sexual matters which characterized the Free State and early decades of the Republic?

J. P. Yes, because they trusted the moral grounds of their thought. I don't believe it's true now. My wife - she was catholic, but she was utterly agnostic — would say to me "That bloody Church, we have no life" because I would not use contraceptives; that's how I was trained, to say "I won't make a whore of you," which is ridiculous.

Now it is all different, but I tried to live accordingly. It was very hard though to lie in bed with a person you loved, a bed with rules, you know. My wife and I were very united; she was great to me, she was a very, very intelligent woman, a gifted person, much more so than I, and she was very gentle and loving and caring. But it certainly didn't improve the opportunities to enjoy our love. Oh yes, I condemn them absolutely for that. That's this Jansenistic view that all sorts of bodily functions are an expression of evil, that anything like that is wrong, when in fact that's nature, and indeed sexual congress should bind together.

But I thought, I still think, that there is a kernel of morality that must be observed. Now, take abortion. Of course, when the life of the mother is in danger there is no question about it, but I feel that abortion must not be accepted as a licence to lie around promiscuously with everybody and anybody, and then say "It doesn't matter, she'll have an abortion." That's wrong, because I do think that if life is created you can't just keep 
throwing away the embryo. Because life is sacred, even at that stage, and I would have a strict view about that. But on the other hand, not the pro-lifers here, who are a joke, and they are the greatest liars under the sun, they are just fixed on maintaining this pro-life.

R. G. You have recently confessed that while living in Dublin your heart was pining "for what lay beyond" and that you wouldn't like to live again in Dublin ("Away to the Hills"). Similarly, in your novels characters long to go out to the seaside, and to the mountains, but on the other hand, Dublin is very vividly evoked, and the characters feel very attached to it. How would you explain those mixed feelings towards the city?

J. P. Well I was very attached to Dublin, but Dublin now is not the place I grew in. I was born beside the sea, near to where the river Liffey enters Dublin Bay. At that time the city and the sea were like companions. We used to walk the strands, and all our adventures were there. Even though the strand was ebbed there would be always little streams, you know, coming through it, and we used to catch green crabs. They used to have a little $\mathrm{V}$ in the under part, and we would open this and look inside because we believed that's where the crab kept its money, from wrecks of ships. And we would steal the fishermen's boats for a little rowing. You know, that sort of childish things.

Ringsend was a great fishing centre then; the salmon came up there - I believe they are not coming up now. And the nets would be hanging to dry on the wall, the sea wall, with bits of seaweed drying on it, and the fishermen would be mending them, and the boys used to bring the girls out in the boats. I remember a beautiful night. It must have been in autumn because it was quite dark - and a lovely moon, and a lot of cold - and this boatful, very long boat with boys rowing, and a fellow playing the melodeon, and they were all singing "Carolina Moon Keep Shining." They were very good at Ringsend at harmonizing, rather like the Welsh; they'd sing and usually harmonize with a kind of descant, you know, above rather than below, but it doesn't matter, they were very good at it. And they were singing and when they lifted the oars, the drips from them would be like silver things dropping into the sea. I was about twelve and I thought "Oh, this is beautiful." The music was a simple tune but it set the mood, you know, because of the nostalgia. I'll never forget that. I thought that was a moment of perfection. These were ordinary lads and ordinary girls coming out on a Sunday, having a little row in the moonlight, and being romantic. Now, it couldn't be terribly romantic in a crowded boat, but it didn't matter, they were beside the girl they liked, or she beside the boy she liked. It was fun, and they were singing and they were having a great time. I'll never forget that. I think that really got me on music, when I realised how beautiful melody was and how beautiful harmony was. And of course, the beautiful setting too.

Of course, in those days we were very poor. I remember, in the nineteen fifties, asking young Jim Larkin, Larkin's son: "Jim, what is the biggest change you've noticed in the last years?" He said: "I'll tell what I see, the children are much better dressed, they have shoes on them, they have shorts on them." But before that they were mostly dressed with the father's cut-down suits, you know, if you cast off your trousers, then the mother cut the legs off, and did things, and gave them to the children. 
But, in spite of poverty, Dublin was a good place to grow up in. It offered natural compensations: it was open to the sea, and the mountains were always visible and easily accessible.

R. G. Talking about your youth in "Remembrance of Things Past" you have said that the high rate of mortality caused by consumption, and "a wide range of other fatal and commonplace disorders implanted at an early age a nagging understanding of the frailty of the human condition." References to death recur in your work. Is death something which particularly disturbs you?

J. P. I was conscious of death from a very early age. We were a very close family, and I would be staying with my grandfather and grandmother lots of weekends, and going down for holidays there. You know, this doesn't mean I was being neglected by my father and mother, they loved me too, but in the summer I used to walk down to them. And I loved my aunts - I had about ten mothers, really. My real mother was my real mother, but my aunts were surrogate mothers. I was the first born, you see. My mother was the first married of her crowd and my father was the first married of his side, and I was the first born. They used an expression, they used to say that "the sun shone over me arse." They were awfully good but my grandmother died when I was about five, and that broke my heart for I was terribly fond of her. I remember that when she died she was put in - they call it the sitting-room now, but we used to call it the parlour - and my mother lifted me up and said, "Now, kiss your grandmother" and I screamed, I was terrified. I had to be brought in hysterics down to the neighbours, who were friends of my aunts, and they put me up for the night and calmed me down, and after a while, you know kids, they get over. And shortly after that, about five years after that my grandfather died, my maternal grandfather. He was a carpenter, he also played the violin, by the way; and he bought me, not my first violin, my dad did that, but he bought me my second one. I remember he brought me down to a pawn shop and bought me a violin for a pound - the fellow said you wouldn't get a good one for less. And then, of course, when I was twelve my father died and for me that was the end of the bloody world. So, that's why death figures so prominently in my work. You get it especially in Farewell Companions, which is partly based on my childhood and youth.

So, that's where my material comes from, that's what you call experience. When I was twenty I didn't realise that was experience, but when I grew a bit older and I looked back at these memories, I said to myself: "That is experience. Just write about that. Now you can introduce it, now you can dimension to it." 